The University of Maine

DigitalCommons@UMaine

Marine Sciences Faculty Scholarship

School of Marine Sciences

$1-1-1977$

\title{
Within-Season Homing Movements of Displaced Mature Sunapee Trout (Salvelinus Alpinus) in Floods Pond, Maine
}

James McCleave

University of Maine - Main, mccleave@maine.edu

G. W.Labar

F.W. Kircheis

Follow this and additional works at: https://digitalcommons.library.umaine.edu/sms_facpub

\section{Repository Citation}

McCleave, James; Labar, G. W.; and Kircheis, F. W., "Within-Season Homing Movements of Displaced Mature Sunapee Trout (Salvelinus Alpinus) in Floods Pond, Maine" (1977). Marine Sciences Faculty Scholarship. 144.

https://digitalcommons.library.umaine.edu/sms_facpub/144 


\title{
Within-Season Homing Movements of Displaced Mature Sunapee Trout (Salvelinus alpinus) in Floods Pond, Maine
}

\author{
James D. McCleave and George W. LaBar ${ }^{1}$ \\ Migratory Fish Research Institute and Department of Zoology \\ University of Maine, Orono, Maine 04473 \\ FrEDERICK W. KircheIS \\ Maine Department of Inland Fisheries and Wildlife \\ Bangor, Maine 04401
}

\begin{abstract}
Tagging, displacement and recapture, and ultrasonic tracking of displaced mature Sunapee trout (Salvelinus alpinus) in Floods Pond, Maine, demonstrated that rapid within-season homing occurs in this relict form of Arctic char. Of the trout displaced about $1.8 \mathrm{~km}$ from their spawning ground from 1972 to $1975,9 \%$ to $32 \%$ were recaptured one to four times within the same spawning season in trap nets set on the spawning ground. Eight of 14 trout tracked ultrasonically in 1975 homed in 2.5 to $10.0 \mathrm{~h}$. Movements of the homing fish were variable; some trout homed paralleling the shoreline, others homed in open water or used a combination of near-shore and open-water movements. Behavior was similar between the sexes and during day and night, although two fish did begin to move just at sundown. Swimming speeds ranged from 15 to $35 \mathrm{~cm} \mathrm{~s}^{-1}$ and averaged about 0.6 body lengths $\mathrm{s}^{-1}$. Swimming directions were not influenced by wind and wave direclion, nor were swimming speeds within individual tracks influenced by cloud cover, wave height, or water depth. Heavy overcast at night may have inhibited movement.

Sunapee trout are apparently familiar with the entire lake and travel widely within it. Visual features are postulated as orientational cues, though use of such cues is not clearly demonstrated by our experiments.
\end{abstract}

The Sunapee trout is a land-locked postglacial relict of anadromous arctic char (Backus 1957; Everhart and Waters 1965), given subspecific status, along with the Quebec red trout and the blueback trout, as Salvelinus alpinus oquassa by Qadri (1974). Only Floods Pond, Hancock County, Maine supports a native, reproducing population of Sunapee trout. The Sunapee trout was recently introduced into seven other Maine lakes by the Maine Department of Inland Fisheries and Wildlife in an effort to expand its distribution and insure its survival.

Studies of the reproductive biology of Sunapee trout have been undertaken (Kircheis 1976) to help understand why introductions into other lakes have not yet established reproducing populations. In Floods Pond Sunapee trout spawn at night during October and November in a restricted shoal area of $10-100$ $\mathrm{cm}$ rubble off a point of land exposed to wave action from nearly every direction. Other

\footnotetext{
${ }^{1}$ Present address: School of Natural Resources, University of Vermont, Burlington, Vermont 54301.
}

areas of the lake with similar substrata are not utilized.

In conjunction with spawn-taking operations and tagging for other life history studies (Kircheis 1976), it was noted that many ripening, ripe, or even artificially stripped fish displaced $1.8 \mathrm{~km}$ from the spawning ground returned to the spawning ground within a short time and also used the area in subsequent years. This observation led to tag and recapture studies to be reported here to determine if the fish home and also to the primary purpose of the present study which was to determine by ultrasonic telemetry the detailed within-season homing movements of displaced mature Sunapee trout. Specifically we wished to determine 1) pattern(s) of movement, if any; 2) swimming speeds; and 3 ) whether homing occurred both day and night.

Homing has been reported for several species of chars, e.g. by Frost (1963) for a landlocked subspecies of arctic char, Salvelinus alpinus willughbii, by O'Connor and Power (1973) for brook trout (S. fontinalis), by 

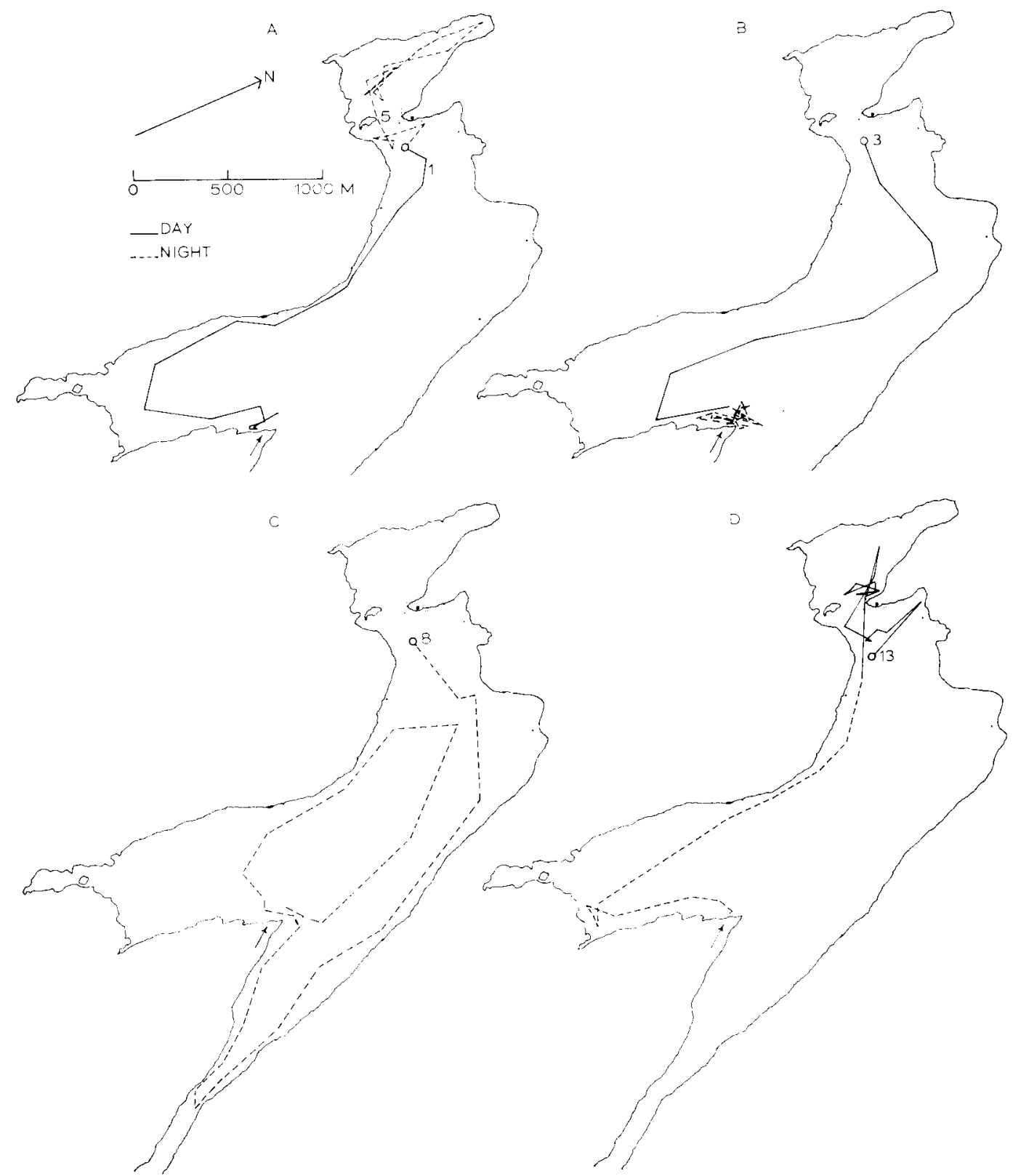

Figure 1.-Ultrasonic tracks of five Sunapee trout in Floods Pond following displacement from their spawning ground. Open circle is release point, arrow indicates spawning ground.

Armstrong (1974) for Dolly Varden (S. malma), and by Martin (1960) and Rahrer (1968) for lake trout (S. namaycush); however, such behavior is not nearly as well studied as in the genera Salmo and Oncorhynchus.
METHODS

\section{Study Area}

Floods Pond is an oligotrophic lake located in a hilly wooded area of the Union River drainage in south-central Maine. The lake is 
265 hectares in area (Fig. 1) with a maximum depth of $45 \mathrm{~m}$ and a mean depth of $12.5 \mathrm{~m}$. Tag and recapture studies were conducted from mid-October to the end of November, 1972-1975. Ultrasonic tracking was done between 15 October and 9 November 1975.

\section{Tagging-Recapture}

Sunapee trout were captured on the spawning ground in two trap nets, which were usually tended in the morning. The fish were transported in covered tubs to the $\mathrm{NW}$ end of the lake for examination. They were then lightly anesthetized in an approximately $1: 9$, 500 MS222 solution, and total length, weight, sex, degree of maturity, fin-clip or tag number, if any, were recorded.

Fish for conventional tagging were marked with jaw tags and a temporary clip of the upper tip of the caudal fin to indicate the fish had been processed during the current season. Many of the mature fish were then stripped and released or were held in live cars up to a few days prior to stripping and release. Immature or unripe fish were released immediately. Fish were released at the shoreline just $\mathrm{NW}$ of the ultrasonic tracking release point (Fig. 1).

Since the traps were not necessarily checked each day, and they did not catch all fish on the spawning ground, and they mostly caught fish at night, homing times based upon times of recapture are overestimated and thus not presented.

\section{Ultrasonic Tracking}

Fish for ultrasonic tracking were captured and processed similarly to fish for conventional tagging. Mature, unstripped fish were jaw-tagged (if untagged) and the transmitter was pushed down the esophagus into the stomach with a glass rod. Caudal clips were applied in only a few cases. Transmittertagged fish were usually placed in a live car at the release site for at least $1 \mathrm{~h}$ and up to 24 $h$ for recovery from anesthetic before tracking; one was released immediately. Fish in the live car had access to the water surface.

The tracking system consisted of a receiver installed in a $5 \mathrm{~m}$ outboard runabout. A $360^{\circ}$ rotatable directional hydrophone was mounted on the starboard side and suspended $0.5 \mathrm{~m}$ below the water surface (McCleave and Horrall 1970). Ultrasonic transmitters were pulsed type, usually $55-60 \mathrm{kHz}$, but one 120 $\mathrm{kHz}$ and one $230 \mathrm{kHz}$ transmitter were used. All were $8-10 \mathrm{~mm}$ diam. $\times 32-36 \mathrm{~mm}$ long.

All but one of the 14 tracks began at the live car $125-250 \mathrm{~m}$ offshore at the NW end of the lake about $1.6 \mathrm{~km}$ from the spawning ground (Fig. 1); one began at the shoreline at the NW end. After a fish was released the boat alternately waited and moved toward the fish on bearings obtained from the hydrophone. We moved close to the fish to make a position plot each $15 \mathrm{~min}$.

Most position plots were made by measuring the two adjacent horizontal angles between three landmarks with a sextant. Some nearshore plots were made by observing landmarks on an aerial photograph. At each position, we measured wind direction and velocity, wave direction and water depth. Cloud cover and wave height were estimated.

\section{Data Analysis}

Tracks were plotted on a $1: 7,900$ work map. A three-arm protractor was used to plot sextant sightings and field notes to plot other positions. Based on straight lines between successive points, swimming azimuths, distances, speeds and straightness indices (Stasko et al. 1973) were determined. Swimming azimuths were expressed relative to wind direction and Rayleigh's test (Batschelet 1965) used to determine if there was significant clustering for each track. Wave direction measurements were not utilized, since wind and wave direction usually coincided, and wind directions were more accurately measured. Correlation coefficients between swimming speed and cloud cover, wave height, and water depth were calculated for each track.

\section{RESULTS \\ Tagging-Recapture}

In the years 1972 through $1975,9 \%$ to $32 \%$ of the displaced Sunapee trout were recaptured on the spawning ground at least once within the same spawning season (Table 1). Three percent were recaptured two to four times 
within the season. Homing percentages are underestimated, since the traps did not catch all fish on the spawning ground. However, these data establish that substantial withinseason homing occurs, often within $24 \mathrm{~h}$. Yearly comparisons are not warranted, since trapping effort was not the same all years. Greatest effort was in 1975, and the percentage recaptured was greatest that year. Consistently, slightly more females than males were recaptured each of the $4 \mathrm{yr}$, but the overall difference was not significant $\left(\chi^{2}=5.1,3 \mathrm{df}\right.$, $P>0.05$ )

\section{Ultrasonic Tracking}

Fourteen Sunapee trout were tracked, ${ }^{2}$ and eight of these were tracked back to the spawning ground. Homing time ranged from $2 \mathrm{~h}$ $25 \mathrm{~min}$ to $10 \mathrm{~h}$, and swimming distance from 2.8 to $8.4 \mathrm{~km}$ (Table 2). One trout was tracked home twice (nos. 1 and 3 ) and another tracked nearly home a second time (nos. 2 and 6).

Movements of the trout varied from individual to individual, but widely ranging movements were typical even among homing trout. Three trout (nos. 1, 10 and 13, Fig. IA,D) were tracked home along the westerly shoreline. These trout travelled around the SW arm rather than crossing it directly to the spawning area. Trout on track nos. 2, 3 (Fig. 1B) and 11 , homed by travelling almost the entire distance in deep, open water, though nos. 3 and II moved approximately parallel to the westerly shoreline. Trout nos. 8 (Fig. 1C) and 14 homed using a combination of along-shore and open-water movements; nos. 4 and 6, tracked nearly home, showed the same combination, plus considerable wandering along shore and in open water. Trout no. 8 (Fig. 1C) exhibited extensive movement along the easterly shore, long, straight movements in open water, and the ability to cruise nearly the entire lake in relatively short time.

Twice (nos. 4 and 8, Fig. 1C) trout swam right through the spawning ground and subsequently made substantial movements before returning. After arriving initially, some trout

\footnotetext{
${ }^{2}$ Twelve individuals were tracked; track nos. 1 and 3 were of the same trout, as were track nos. 2 and 6 .
}

TABLE 1.-Recaptures within the spawning season on the spawning ground of Sunapee trout tagged and displaced about $1.8 \mathrm{~km}$ from the spawning ground.

\begin{tabular}{|c|c|c|c|c|}
\hline \multirow[b]{2}{*}{ Year } & \multirow[b]{2}{*}{ Sex } & \multirow[b]{2}{*}{$\begin{array}{l}\text { Number } \\
\text { displaced }\end{array}$} & \multicolumn{2}{|c|}{$\begin{array}{c}\text { Number homing fish } \\
\text { recaptured }\end{array}$} \\
\hline & & & Total & $\begin{array}{l}\text { More than } \\
\text { once }\end{array}$ \\
\hline \multirow[t]{2}{*}{1972} & $\begin{array}{c}0^{*} \\
\stackrel{1}{1} \\
\text { Immature }\end{array}$ & $\begin{array}{r}80 \\
173 \\
6\end{array}$ & $\begin{array}{r}6 \\
17 \\
0\end{array}$ & $\begin{array}{l}\text { Not } \\
\text { recorded }\end{array}$ \\
\hline & Total & 259 & 23 & \\
\hline \multirow[t]{2}{*}{1973} & $\begin{array}{c}\delta^{*} \\
q \\
\text { Immature }\end{array}$ & $\begin{array}{r}153 \\
165 \\
11\end{array}$ & $\begin{array}{r}26 \\
41 \\
0\end{array}$ & $\begin{array}{l}1 \\
8 \\
0\end{array}$ \\
\hline & Total & 329 & 67 & 9 \\
\hline \multirow[t]{2}{*}{1974} & ơ & $\begin{array}{l}71 \\
79\end{array}$ & $\begin{array}{r}7 \\
14\end{array}$ & $\begin{array}{l}1 \\
0\end{array}$ \\
\hline & Total & 150 & 21 & 1 \\
\hline \multirow[t]{2}{*}{1975} & $\begin{array}{c}\sigma^{*} \\
q \\
\text { Immahure }\end{array}$ & $\begin{array}{r}178 \\
85 \\
1\end{array}$ & $\begin{array}{r}53 \\
31 \\
0\end{array}$ & $\begin{array}{r}7 \\
12 \\
0\end{array}$ \\
\hline & Total & 264 & 84 & 19 \\
\hline
\end{tabular}

(e.g. nos. 3 and 10, Fig. 1B) wandered considerably onto and off the actual spawning shoal.

The remaining four trout (nos. 5, 7, 9, and 12) wandered extensively near shore or in open water or both during the tracking period. One of these (no. 5, Fig. 1A) entered the cove at the NW end of the lake and remained there. Only one other trout (no. 13, Fig. 1D) entered that cove.

All patterns of behavior mentioned above were observed during both day and night. However, on two occasions (nos. 13 and 14, Fig. 1D) sunset seemed to trigger movement. Both trout had wandered for 4 to $5 \mathrm{~h}$ during afternoon, but within a few minutes of sundown began moving rather directly toward the spawning area (Fig. 1D). In both cases swimming speeds increased greatly (about $180 \%$ and $260 \%$ ) after nightfall, and in one case the straightness index increased sixfold (Table 2). Within other tracks, swimming speeds and straightness indices were inconsistently variable from day to night (Table 2 ). Mean straightness indices and swimming speeds as centimeters per second and body lengths per second were not significantly different from day to night ( $t$-test; $P>0.05$ ).

Swimming direction was apparently not influenced by wind direction (and therefore probably not by wave direction). In 13 tracks 
TABLE 2.-Tracking times, minimum swimming distances, minimum swimming speeds, and straightness indices of Sunapee trout during day portions, night portions, and entire tracks. Relative swimming speeds are in body lengths (BL) swum per second. H after the trach number indicates trout tracked home to the spawning area; $R$ indicates recaptured. For most tracks distances and swimming speeds were calculated only on movement portions, not including time before movement began or wandering about the spawning ground after homing.

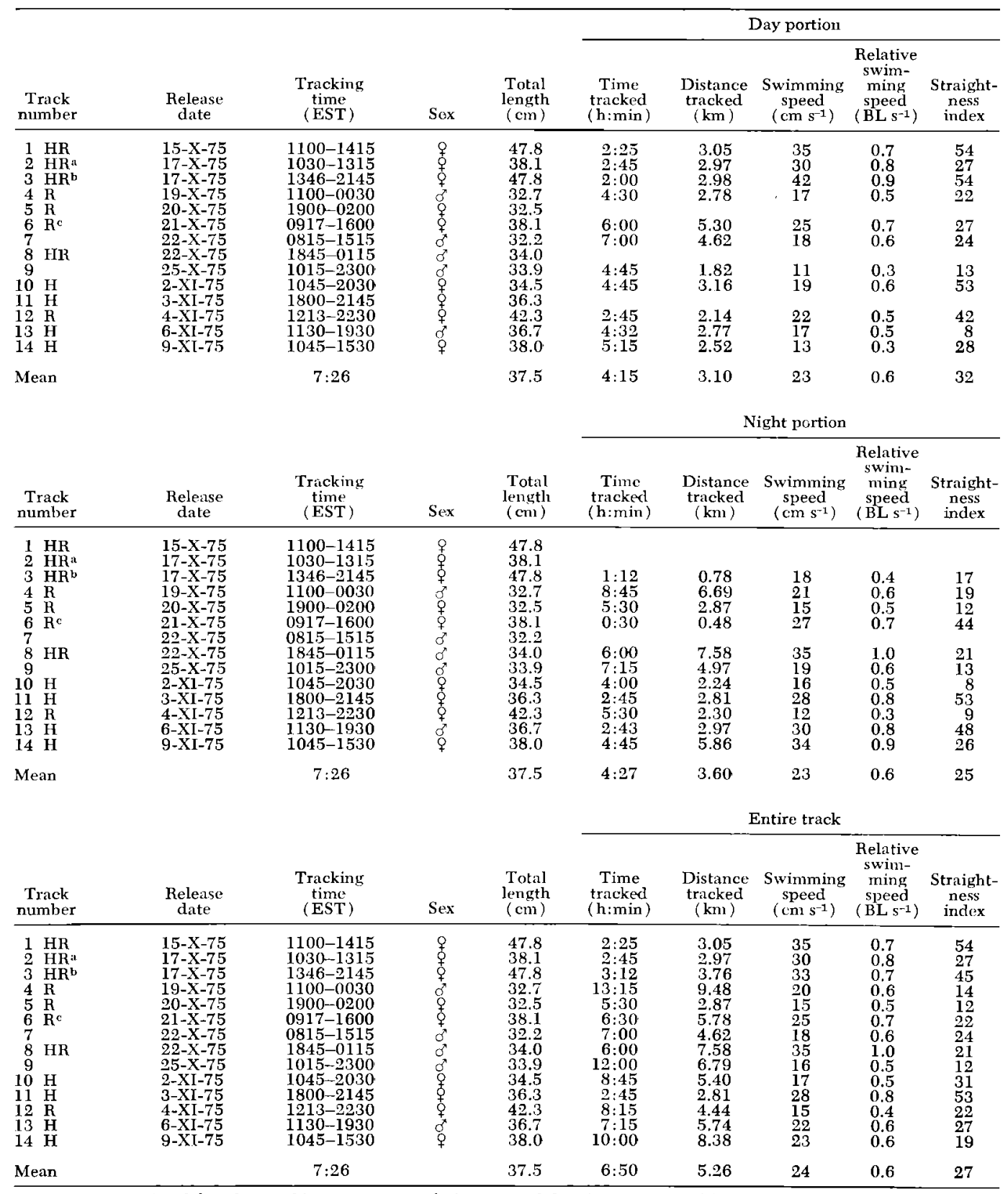

a Transmitter signal lost by tracking crew part of time, actual homing time $=6: 45$.

b Same trout as track number 1 .

c Same trout as track number 2 . 
during which there was wind, the swimming directions of only one trout (no. 10) were significantly clustered when plotted relative to the wind (direction re wind $=31^{\circ}$, vector length $=0.3069, P<0.05)$. Correlations of swimming speeds with amount of cloud cover, wave height, and water depth were inconsistent and highly variable suggesting little, if any, effect of these environmental factors on swimming speed. Possible influences of cloud cover and sun or moon visibility upon movement patterns were difficult to assess. Only one trout was tracked entirely under overcast skies at night (no. 5, Fig. 1A) when visual cues were minimal; it wandered in a restricted cove at the northwest end of the lake. Two other trout tracked entirely at night under clearer skies with moonlight homed. There was no evidence of cloud influence during the day.

Swimming speeds ranged from 15 to $35 \mathrm{~cm}$ $\mathrm{s}^{-1}$ and 0.5 to 1.0 body lengths (BL) $\mathrm{s}^{-1}$, and straightness indices ranged from 12 to 54 for entire tracks (Table 2). Speeds and straightness indices of the four trout classed as wanderers averaged only about $60 \%$ of those of all other tracks. Although highly variable, average swimming speed was significantly related to total length according to the least squares regression equation:

$$
Y=-5.391+0.775 X
$$

where $Y=$ swimming speed in $\mathrm{cm} \mathrm{s}^{-1}, X=$ total length in $\mathrm{cm}(P<0.05$ that the regression coefficient is not different from zero). When swimming speed $(Y)$ is expressed as body lengths per second the regression becomes non-significant $(P>0.10)$ :

$$
Y=2.200+0.003 X
$$

i.e., on the average trout swam $0.6 \mathrm{BL} \mathrm{s}^{-1}$ regardless of fish size.

There were no sex differences in movement patterns or in swimming speeds. Both males (average length $=34 \mathrm{~cm}$ ) and females (average length $=40 \mathrm{~cm}$ ) swam at just over 0.6 $\mathrm{BL}{ }^{-1}$ on average.

Eight of the 14 trout tracked $(57 \%)$ were recaptured on the spawning ground after being at large 2 to 21 days (mean 11 days), but the pattern of movement during tracking was neither indicative of the probability of re- capture nor the time until recapture. Four of the eight were tracked home in 2.5 to $6.0 \mathrm{~h}$, yet they were recaptured only after 2 to 16 days. Four other trout tracked home in 2.75 to $10.00 \mathrm{~h}$ were not recaptured, though they were only at large 3 to 10 days before the trap nets were removed. Two fish that wandered extensively during tracking were recaptured after 5 and 17 days.

\section{DISCUSSION}

Gerking (1959) used the term homing in a general sense to mean the return of fish "to a place formerly occupied" following natural or artificial displacement. No complex orientation mechanism is necessarily implied by the term homing, but the animal must possess some means of recognizing "home." The mechanisms underlying homing may range from use of search and landmarks to true bicoordinate navigation (Hasler et al. 1958). Search may be random or patterned.

Since there is but a single spawning area in Floods Pond, the Sunapee trout by definition must exhibit natal homing and repeat homing in subsequent spawning seasons. Our data demonstrate, in addition, that these trout can home quickly within a single spawning season.

More significant, however, is the observation that the trout are able to travel extensively about the lake and still return to the spawning ground relatively quickly. We had hypothesized that the trout would return rather directly to the spawning ground during the day or after nightfall, or that they would wander near the release point as, for example, some displaced cutthroat trout (Salmo clarki) are known to do (McCleave and Horrall 1970; McCleave and LaBar 1972). The wandering behavior might indicate an inability to home quickly or a disruption of behavior caused by experimental procedures. Some Sunapee trout did home rapidly and directly (nos. 1, 2, 3, 11; Fig. 1A,B), while others wandered near the release point (nos. 5,9). The movements of several other trout (e.g. nos. 4, 8, 14; Fig. IC) were extensive, but they did not appear disoriented. These movements suggest the interpretation that Floods Pond is sufficiently small that trout can learn features of the entire lake. They are able to move widely about the 
lake, but are capable at any given time of moving quickly onto the spawning ground.

We have some circumstantial evidence to support the interpretation that Sunapee trout may make daily movements on and off the spawning ground. Multiple recaptures suggest that trout spend a considerable time in the spawning area, but our observations show that the area is devoid of trout during the day. We often relocated previously tracked trout with functional transmitters (including some tracked home) in various parts of the lake during the day and near the spawning area at night. If this is a normal behavior, Sunapee trout must make repeated use of their homing ability within a single season. Tracking of fish released on the spawning ground would be instructive in this regard.

If Sunapee trout are familiar with features of the lake, it is tempting to speculate that their orientation in the lake is based in part upon visual cues above or below the water surface. For example, five trout exhibited movements essentially paralleling the western shoreline, but sometimes substantially offshore (see Fig. IA,B,D). The western shore is a high, steep bluff covered with dark trees. To an abovewater observer, it makes a prominent visual contrast with the sky, particularly in the afternoon when most tracking occurred. It is also prominent on clear nights. Two trout tracked at night under full moon were followed in part along the eastern shoreline, also a high bluff over which the moon rose (see Fig. 1C). Underwater features, such as huge boulders and gravel bars, are prominent and easily recognizable to divers. While they possibly contribute to orientation, they alone cannot account for long straight movements observed in open water.

\section{ACKNOWLEDGMENTS}

We thank K. A. Turgeon for assistance in the field, in analysis, and in preparation of the figure. We appreciate the critical comments on the manuscript by Messrs. Edward Gardella and Kendall Warner, and we acknowledge the cooperation of the Bangor Water District.

\section{LITERATURE CITED}

Armstrong, R. H. 1974. Migration of anadromous Dolly Varden (Salvelinus malma) in Southeastern Alaska. J. Fish. Res. Board Can. 31: 435444.

Backus, R. H. 1957. The fishes of Labrador. Bull. Am. Mus. Nat. Hist. 113: 279-337.

Batschelet, E. 1965. Statistical methods for the analysis of problems in animal orientation and certain biological rhythms. Am. Inst. Biol. Sci., Wash. $57 \mathrm{pp}$.

Everhart, W. H., and C. A. Waters. 1965. Life history of the blueback trout (Arctic char, Salvelinus alpinus Linnaeus) in Maine. Trans. Am. Fish. Soc. 94: 393-397.

Frost, W. E. 1963. The homing of charr Salvelinus willughbii (Günther) in Windermere. Anim. Behav. 11: 74-82.

Gerking, S. D. 1959. The restricted moveinent of fish populations. Biol. Rev. 34: 221-242.

Hasler, A. D., R. M. Horrall, W. J. Wisby, and W. BraEmer. 1958. Sun-orientation and homing in fishes. Limnol, Oceanogr. 3: 353-361.

Kircheis, F. W. 1976. Reproductive biology and early life history of the Sunapee trout of Floods Pond, Maine. Trans. Am. Fish. Soc. 105: 615619.

Martin, N. V. 1960. Homing behaviour in spawning lake trout. Can. Fish Cult. 26:3-6.

McCleave, J. D., and R. M. Horrall. 1970. Ultrasonic tracking of homing cutthroat trout (Salmo clarki) in Yellowstone Lake. J. Fish. Res. Board Can. 27: 715-730.

__, AND G. W. LaBar. 1972. Further ultrasonic tracking and tagging studies of homing cutthroat trout (Salmo clarki) in Yellowstone Lake. Trans. Am. Fish. Soc. 10I: 44, 54.

O'Connor, J. F., and G. Power. 1973. Homing of brook trout (Salvelinus fontinalis) in Matamek Lake, Quebec. J. Fish. Res. Board Can. 30: 1012-1014.

QAdri, S. U. 1974. Taxonomic status of the Salvelinus alpinus complex. J. Fish. Res. Board Can. 3I: 1355-1361.

RaHrek, J. F. 1968. Movements of adult lake trout in Lake Superior. Trans. Am. Fish. Soc. 97: 481484.

Stasko, A. B., R. M. Horrall, A. D. Hasler, and D. Stasko. 1973. Coastal movements of mature Fraser River pink salmon (Oncorhynchus gorbuscha) as revealed by ultrasonic tracking. J. Fish. Res, Board Can. 30: 1309-1316. 